\title{
The embryology of the retinal pigmented epithelium in dwarf geckos (Gekkota: Sphaerodactylinae): a unique developmental pattern
}

\author{
Ricardo A Guerra-Fuentes ${ }^{1}$, Juan D Daza ${ }^{2,3^{*}}$ and Aaron M Bauer ${ }^{2}$
}

\begin{abstract}
Background: The retinal pigmented epithelium (RPE) is a rounded shaped structure in almost all lizards. In the New World dwarf geckos, this structure shows an unusual morphology. In addition to this ocular character, we describe notable differences in the development of these geckos in comparison with available developmental staging tables for other geckos and squamate reptiles.

Results: We identified two main patterns of development of the RPE for squamates. These patterns were mapped onto a metatree of concordant hypotheses of squamates based on molecular data. During post-ovopositional stages the representative species of sphaerodactyls exhibit a RPE layer that transforms gradually from an ovoid form into the generalized spherical form. Sphaerodactyls are the only group of squamates in which this pattern is known.

Conclusions: This transition might be circumstantial evidence that the accessory RPE plays a role in providing additional protection for their apomorphic concaviclivate temporal fovea. We also report the presence of conjunctival papillae in a developmental stage prior to the formation of scleral ossicles. This developmental progression is similar to that of birds and turtles.
\end{abstract}

Keywords: Squamata, Eye development, Concaviclivate temporal fovea, Conjunctival papillae

\section{Background}

The New World dwarf geckos (Sphaerodactylinae) or 'sphaerodactyls' include about 164 species, accounting for more than $11 \%$ of the known diversity of the Gekkota [1-3]. Originally the term "sphaerodactyls" was used to refer exclusively to members of genus Sphaerodactylus [4-9], but it has more recently been used to include the genera Gonatodes, Lepidoblepharis, Chatogekko, Coleodactylus, Pseudogonatodes, and Sphaerodactylus $[1,10,11]$; in this paper, we follow the latter usage.

Sphaerodactyls are diurnal and represent some of the most extremely miniaturized extant amniotes (viz. Sphaerodactylus ariasae and S. parthenopion, [12,13]),

\footnotetext{
* Correspondence: juand.daza@gmail.com

${ }^{2}$ Biology Department, Villanova University, 800 Lancaster Avenue, Villanova, PA 19085-1699, USA

${ }^{3}$ Department of Biological Sciences, Sam Houston State University, 1900 Avenue I, Huntsville, TX 77341-2116, USA

Full list of author information is available at the end of the article
}

equaled only by tiny leaf chameleons from Madagascar $[14,15]$. Some sphaerodactyls are climbers and utilize vertical surfaces $[16,17]$, but the majority of them are surface dwellers, found in forest or littoral leaf litter $[4,18,19]$. They combine their small size with a secretive lifestyle, which is common among lizards [20] and is an ecological niche that is known to have been occupied by members of Squamata as early as 120 million years ago [21].

Sphaerodactyls are diurnal and develop a shallow, bowllike or concaviclivate temporal fovea in the retinal tissue $[22,23]$. These geckos are also known to be affected by variations of environmental factors such as illumination [24]. For example, Sphaerodactylus macrolepis from forested habitats detects motion better in dim light than conspecifics from coastal areas, which detect movement better in much brighter conditions [25].

Binocularity (stereopsis) for deep perception in this group might also be facilitated because of their large

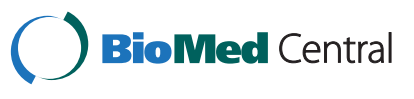


eyes and generally narrow snouts [JDD, pers. obs.], analogous to other squamates with binocular vision, such as vine snakes [26]. Narrow snouts coupled with ocular adaptations to diurnal habits suggest that this group of geckos may exhibit some anatomical differences from other lizards, including nocturnal geckos.

Sixty years ago, Garth Underwood developed a classification of geckos using visual system characters [22,27-29]. Under this classification, sphaerodactyls were placed in a separate family based on several morphological characters, such as presence of a temporal fovea, a round pupil (elliptical with straight vertical margins when closed), and presence of a brille covering the eye [22,29], in combination with additional osteological [30] and integumentary [31] characters.

Subsequent to Underwood's classification of geckos [29], morphological evidence has been accumulated in support of the monophyly of the sphaerodactyls and their relationships with other gekkotan genera [11,32-39]. Recent molecular evidence has corroborated the split of sphaerodactyls from the Gekkonidae sensu stricto and grouped them together in an expanded Family Sphaerodactylidae with the Caribbean genus Aristelliger and the Old World genera Euleptes, Pristurus, Quedenfeldtia, Saurodactylus and Teratoscincus ([1,2], Figure 1). Although Underwood's classification is outdated, some of the characters that he used still have taxonomic utility [40], for example, the eye morphology that he attributed to the sphaerodactyls has also been found in most of the genera recently placed in the family (e.g., Aristelliger, Pristurus, Quedenfeldtia, Saurodactylus, Teratoscincus).

However, the latest molecular and morphological hypotheses of relationships within the Sphaerodactylidae are not entirely congruent [2,39]. Molecular data indicate a single origin for the sphaerodactyls (Figure 1A) whereas morphology suggests that the Northeast African/ Middle Eastern genus Pristurus is nested within the sphaerodactyls (Figure 1B). These two hypotheses also differ from the previous phylogenetic hypothesis based on morphology of the group [11].

Here we investigate in detail a preliminary observation by Werner [41] on eye development in Sphaerodactylus argus in postovopositional stages. Although Werner did not describe in text the changes of the eye during development, he did illustrate a remarkable change in eye morphology across the embryological stages of this species. Using Werner's staging for Sphaerodactylus argus, it can be seen that in embryos at approximately stages 30-31, the outer layer of the optic cup contains an ovoid retinal pigment epithelium (henceforth RPE), extending considerably towards the posterolateral portion of the eye. After stage 31, the iris is clearly differentiated but this pigmentation extends posteriorly, forming an ovoid extension and creating the appearance of a bandit's mask in the embryo. This posterior extension of RPE remains until approximately stage 35 when it gradually becomes less accentuated and the iris becomes more rounded (Figure five in [41]).

In this paper we present information on the embryology of sphaerodactyls, making special reference to eye development and the retinal pigmented epithelium, and contrast this with embryological information from other lizard families, including some nocturnal gekkotans. To date most contributions to the study of gekkotan ontogeny have been descriptions of the external morphology across developmental series [41-45] and osteological descriptions of a few species [46-51]. Only some studies have evaluated the phylogenetic significance of embryological data for squamate systematics [52-57]. This study explores the distribution of two contrasting patterns of development for the eye, and has the potential to provide additional morphological evidence for the understanding of the evolution of this diurnal clade of geckos.

\section{Methods}

Obtaining complete developmental series from natural populations of geckos is difficult because of their small
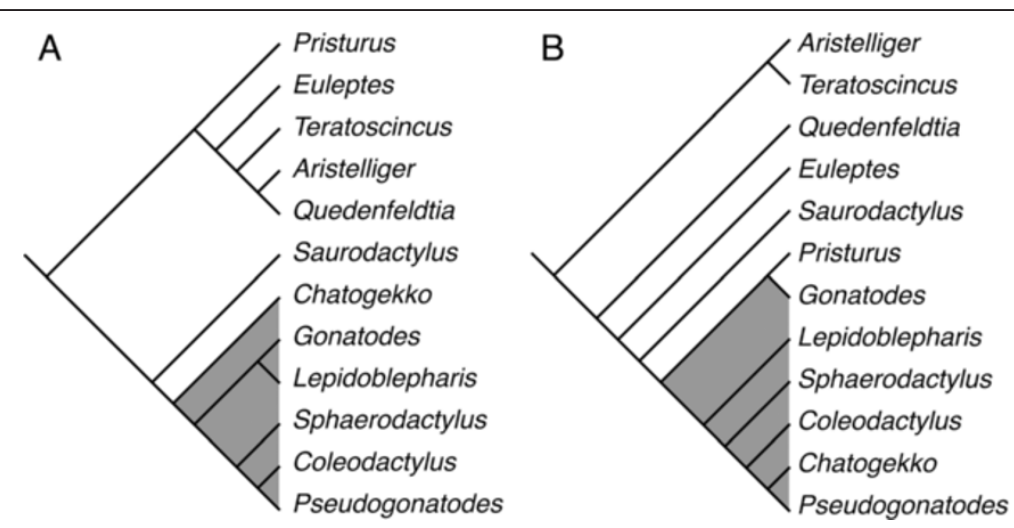

Figure 1 Two alternate hypotheses for the relationships of Sphaerodactylidae. A) Molecular hypothesis [2]; B) Morphological hypothesis [38]. Gray shading indicates the sphaerodactyl group. 
egg clutches. Sphaerodactylids lay a maximum of two eggs per clutch, and most sphaerodactyl species lay only one [1]. We describe morphological changes in squamate specimens during post-ovopositional stages 28-42. We mainly used the developmental diagrams of Sphaerodactylus argus [41] to assess the stages, which follow a previous study [58] on Lacerta agilis. We tried to find some agreement between these development tables and the recently described table for the eublepharid gecko Eublepharis macularius [45], which is based on Gallus gallus [59], but there are substantial differences between comparable stages among species. This observation is congruent with previous comparisons of embryos from different species in which variation in form due to allometry, heterochrony, and differences in body plan and somite number have been reported [60]. We determined the developmental stage by examining external characters such as pharyngeal clefts, eyelids, tympanic aperture, limbs, scale morphology, and pigmentation. These structures have been used in recent developmental staging studies [44,45,61-63].

Direct observations of eye development were observed in 88 embryos of nine species. We examined eye development in embryos from different sphaerodactyl species (Chatogekko amazonicus, Coleodactylus meridionalis, Coleodactylus sp., Gonatodes albogularis, Gonatodes humeralis, Sphaerodactylus macrolepis), representatives from other gekkotan clades (i.e., Gekkonidae, Phyllodactylidae), and other squamate families (Amphisbaenidae, Anguidae, Iguanidae, Polychrotidae, Scincidae, Teiidae, Tropiduridae, Dipsadidae). All squamate embryos in this study were extracted from eggs collected in the field, and cataloged at the Museu de Zoologia, Universidade de São Paulo, Brazil (MZUSP), Museo de Zoología de la Universidad de Puerto Rico, Río Piedras Campus, San Juan, Puerto Rico (UPRRP), and Aaron M. Bauer personal collection at Villanova University, USA (AMB).

The observed visual system characters and additional morphological changes were compared with previous descriptions of the embryology of other squamate groups (i.e., Agamidae, Chamaeleonidae, Dactyloidae, Eublepharidae, Scincidae, Lacertidae) based on literature sources [41,44,45,58,63-69], see Additional file 1 for details on the source of specimens. Development patterns of the REP were mapped as a single character onto a metatree of squamates using the Module Ancestral State Reconstruction (parsimony ancestral states) on Mesquite Version 2.75 [70].

Animals were euthanized according to an approved protocol for ectothermic embryo use (available at: http://www.iacuc.org). The embryos were removed from the egg and immersed in a solution of ethyl 3aminobenzoate methanesulfonate $0.2 \%$. This protocol of euthanasia has been approved by Comissão de Ética no Uso de Animais do Instituto Butantan (Protocol CEUAIB 944/12), Sao Pablo, Brazil and entirely meets the terms of the Institutional Animal Care and Use Committees (IACUC, U.S.A.) and the Federal Constitution (FC, Brazil) Law 11974/2008 for breeding and using animals in teaching and scientific research.

Specimens were photographed at the Museu de Zoologia, Universidade de São Paulo using a modular Leica M205 stereo microscope (Leica Microsystems $\mathrm{GmbH}$, Wetzlar Germany) with a digital color Leica DFC425 microscope camera. Images were processed on a desktop computer running Leica LAS Montage software. Snoutvent length (SVL) measurements were taken for each embryo. Figures in the text are numbered sequentially and include a coordinate system composed of a letter and number. Each letter represents a species, and all the embryos referable to that species are organized sequentially following the letter in their corresponding embryological stage (number in the horizontal rows), for example Figure 2A-28, refers to Gonatodes albogularis at stage number 28 .

\section{Results and discussion}

Post-ovopositional embryology in sphaerodactyls with emphasis on the eye

\section{Stage 28-29}

Non-ocular remarks: The mesencephalon bulges at the back of the head, and the pharyngeal clefts I and II are open. At this stage, forelimb and hindlimb buds are visible, with the former larger than the latter. The paddle-shaped autopodium starts to develop by stage 29 . The tip of the maxillary process reaches the level of the choroid fissure. These stages are represented by two embryos, one of Gonatodes albogularis (Figure 2A-28), and one of G. humeralis (Figure 2B-29).

Eye: An ovoid portion of the eye of specimen in these stages is covered by the RPE, including the posterior region; the choroid is pigmented by a homogeneous layer and the iris is undefined. There is a concentration of melanosomes at the posterior side of the area that corresponds to the iris. The margins of the choroid fissure are still in contact with one another, and persist until about stage 29, as seen in G. humeralis (Figure 2B-29).

Comparison with other squamates: At this stage sphaerodactyls appear similar to Hemidactylus mabouia (Figure 3A-29); the choroid fissure persists, melanosomes of the RPE are concentrated on the equatorial region, and the limb buds show further development, with a paddleshaped autopodium. In other lizards at a corresponding stage (e.g., Eublepharis macularius, Lacerta agilis, Anolis sagrei), the choroid fissure is present, and the limb buds appear as mere protuberances $[45,58,64]$. Sphaerodactyls differ from other lizards in the ovoid shape of the RPE of the eye (Figure 2A-28, 2B-29). 


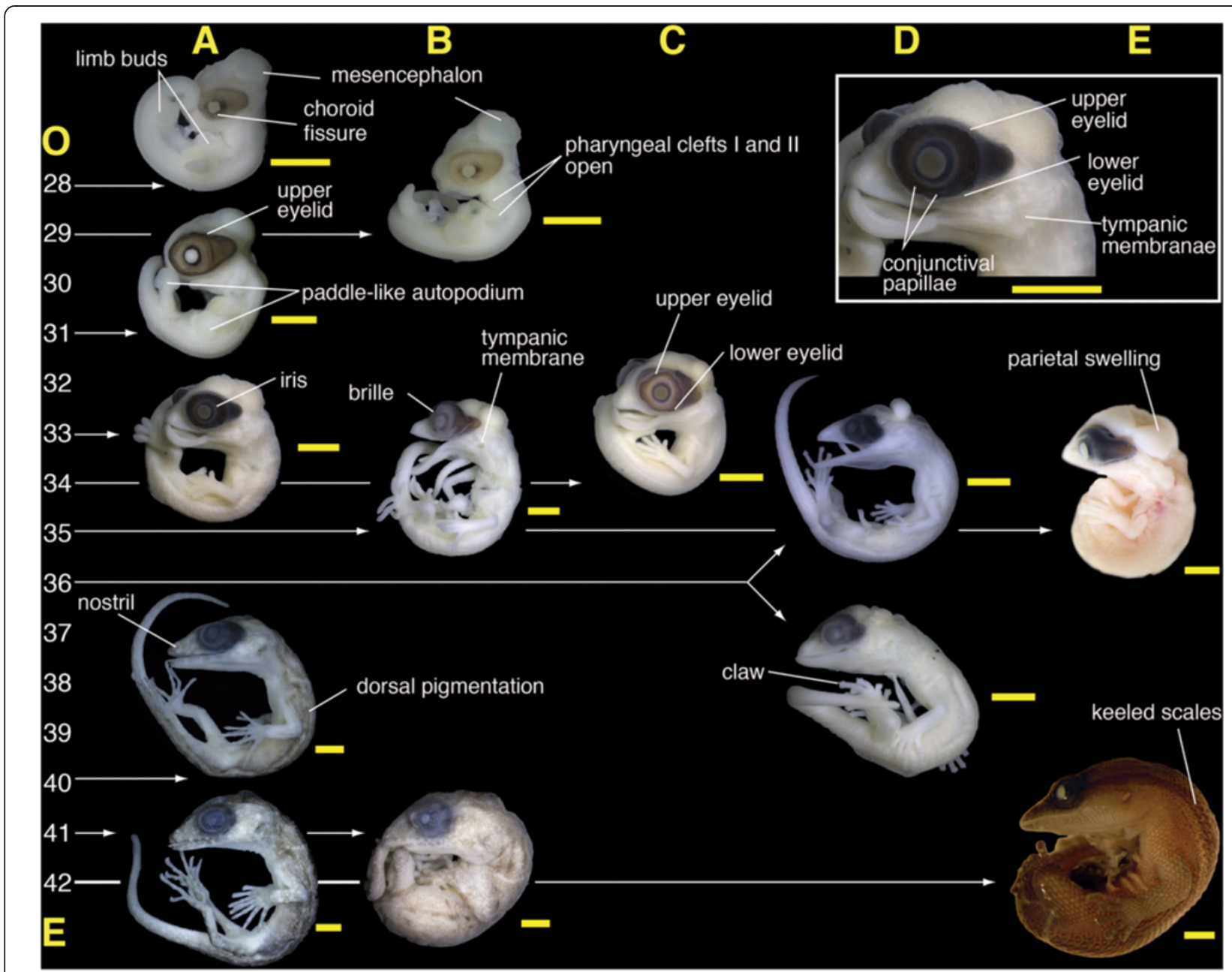

Figure 2 Embryos from five species of sphaerodactyls. Inset, eye detail at the stage 33 of Gonatodes albogularis. A) Gonatodes albogularis; B) Gonatodes humeralis; C) Chatogekko amazonicus; D) Coleodactylus meridionalis and Coleodactylus sp.; E) Sphaerodactylus macrolepis mimetes. Specimen numbers: A-28) MZUSP 99997; A-31) MZUSP 99998; A-33) MZUSP 99999; A-40) MZUSP 100117; A-41) MZUSP 100113; B-29) MZUSP 101107; B-35) MZUSP 101108; B-41) MZUSP 101109; C-34) MZUSP 101105; D-36, upper) MZUSP 101099; D-36, lower) MZUSP 101103; E35, E42) UPRRP uncataloged. Numbers at the left side indicate the approximated embryonic stage between oviposition (0) and eclosion (E) based on the developmental table of Eublepharis macularius [48]. Scale bar equals $1 \mathrm{~mm}$.

\section{Stage 31-32}

Non-ocular remarks: The mesencephalic bulge is less prominent, and the pharyngeal clefts I and II are closed. The maxillary process reaches the nasal capsule and the mandibular process is very close to anterior margin of the eye. Forelimbs and hindlimbs are similar to the previous stage, the autopodium is flat and paddle-like. The stylopodium and zeugopodium are undifferentiated. This stage is represented by Gonatodes albogularis (Figure 2A-31).

Eye: The pigmentation is more uniform than previous stage, the upper eyelid is visible, and the choroid fissure is closed (Figure 2A-31). The iris starts to become delimited, the RPE larger around the iris area than in the posterior part.

Comparison with other squamates: At this stage, the RPE of sphaerodactyls has a distinct ovoid shape; Eublepharis macularius has been described as having a kidney-shaped eye during this stage [45], but its overall shape tends to be more rounded, as it is in other lizards (e.g., Lacerta agilis, Anolis sagrei) $[58,63]$. This can also be seen in slightly later stages of Tupinambis merianae and Polychrus acutirostris (Figure 3C-31, 3D-31). Similar to sphaerodactyls, the upper eyelid covers the dorsal surface of the eye in this stage in Lacerta agilis, and although the upper eyelid has been mentioned in Eublepharis macularius by stage 34 , some thickening of the epithelium surrounding the eye in Eublepharis macularius can be observed as early as stage 32 (See Figure three in [45]). At stage 32 the conjunctival papillae are visible in Polychrus acutirostris.

\section{Stage 33-34}

Non-ocular remarks: The first signs of a tympanic membrane appear between these stages. The parietal area starts 


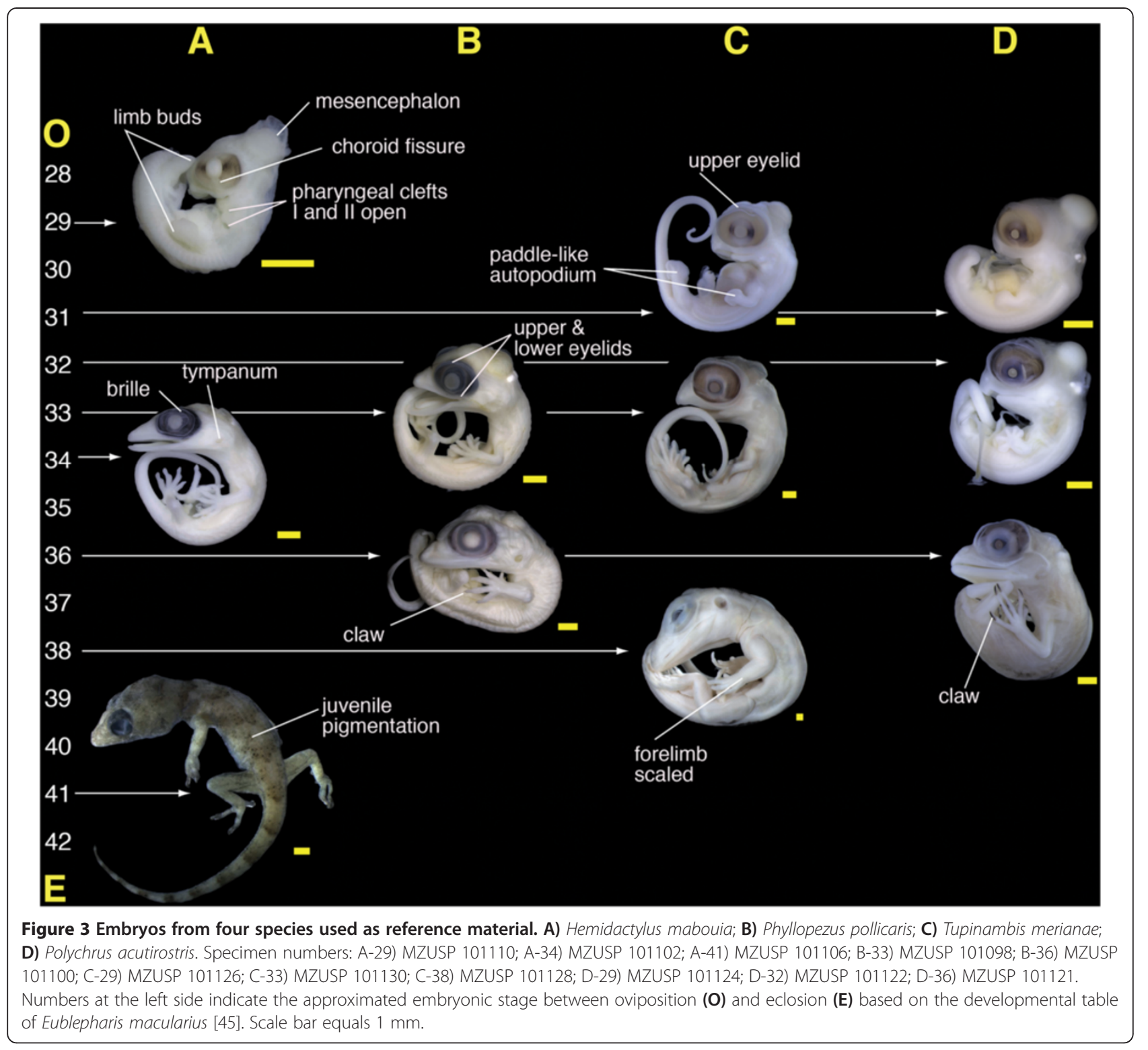

to become swollen. The mandibular process is projected beyond the snout tip yielding a prognathous appearance. The hemipenial buds are visible projecting from the cloaca. Digits well differentiated on both fore limbs and hind limbs, but still webbed. These stages are represented by two embryos, one of Gonatodes albogularis (Figure 2A-33), and one of Chatogekko amazonicus (Figure 2C-34).

Eye: The RPE is more uniform than in the previous stage and both the upper and lower eyelids are visible. The iris is well defined, and the eye still appears ovoid due to the posterior extension of the RPE. Fourteen conjunctival papillae are evident in Gonatodes albogularis at stage 33 (Figure 2A-33). One specimen (MZUSP 100000) at stage 34 had three papillae missing from the posterodorsal region of the eye. The papillae are not visible in stage 34 of Chatogekko amazonicus (Figure 2C-34).
Comparison with other squamates: The tympanic membrane becomes more evident by these stages, as in Hemidactylus mabouia and Tupibambis merianae (Figure 3A-33, 3C-33). In Eublepharis macularius the auditory meatus is apparent by stage 33, whereas this structure is illustrated earlier in Lacerta agilis (Stage 27 in [58]), when the limbs are merely buds. During these stages, digits of sphaerodactyls are more well-differentiated than those of Eublepharis macularius [45], and the degree of interdigital webbing is variable. In sphaerodactyls, Hemidactylus mabouia and Phyllopezus pollicaris the digits are almost free of webbing (Figure 2A-33, 2C-34 and 3A-34, 3B-33), whereas Tupinambis merianae and Polychrus acutirostris are more extensively webbed (Figure 3C-33). Upper and lower eyelids are well developed in sphaerodactyls, Eublepharis macularius, Phyllopezus pollicaris 
(Figure 3B-33). The conjunctival papillae are visible in Tupinambis merianae (Figure 3C-33), but not in Phyllopezus pollicaris (Figure 3B-33).

The RPE of the eye has a roughly circular shape restricted to the iris in all other squamates reviewed, whereas in sphaerodactyls the RPE remains ovoid (Figure 2A-33, 2C-34).

\section{Stage 35}

Non-ocular remarks: The parietal swelling is more prominent and the auditory meatus contains a better-defined tympanum than in previous stages. The mandibular process still extends beyond the snout tip. The digits are nearly free of interdigital webs, and scales start covering the epidermis of the embryos. This stage is represented by three embryos, one of Gonatodes albogularis (MZUSP 100001), one of G. humeralis (Figure 2B-35), and one of Sphaerodactylus macrolepis (Figure 2E-35).

Eye: In the embryo of Gonatodes albogularis the eyelid margin approaches to the margin of the pupil, but in G. humeralis and Sphaerodactylus macrolepis the fusion of upper and lower eyelids into an incipient brille occurs, although a faint suture remains. This character is neomorphic with respect to E. macularius (see Figure four in [45]) and it is produced via peramorphism with respect to all other forms with discrete eyelids. Fusion of eyelids in the Gekkota can be interpreted to have either occurred once with one reversal in the Eublepharidae (geckos with unfused eyelids) or to have been a product of two independent fusions in the Pygopodoidea and the Gekkonoidea exclusive of Eublepharidae. Fusion of eyelids has also occurred in the Xantusiidae, snakes, Amphisbaenia, and some gymnophthalmids, scincids and lacertids [52,71-73]. During this stage, the posterior part of the RPE is comparatively smaller and is concentrated around the iris; therefore the pigmented portion of the choroid changes from ovoid to more bilobular, with a smaller posterior hemisphere. In Gonatodes albogularis the reabsorption of the conjunctival papillae is complete.

Comparison with other squamates: By this stage sphaerodactyls and Hemidactylus mabouia have a well developed brille covering the eye, whereas in some geckos (e.g., eublepharids) and other squamates the eyelids remain separated and become thickened, covering the eye laterally and leaving exposed only the area near the iris. It is difficult to establish correspondence of these stages in squamate groups with attenuated bodies (e.g., amphisbaenians, snakes, and some limb-reduced or limbless squamates such as some gymnophthalmids), especially considering that many of the characters used are based on limb development. In these lineages, where the eye is also covered by a brille, the formation of this structure occurs during intermediate embryonic stages, and the complete fusion of eyelids is accomplished within a few stages $[68,73,74]$.
Sphaerodactyls show a notable proportional reduction of the RPE posterior to the iris, but their eyes still differ considerably from other lizards with a more circular RPE.

\section{Stage 36-38}

Non-ocular remarks: The parietal swelling reduces, the preorbital region of the head is as long or longer than the maximum diameter of the eye, slight mandibular prognathism, digits free of webbing, phalangeal segments begin to differentiate, and initial appearance of claws. Scales cover the whole body except in the parietal region. This stage is represented by two embryos, one each of Coleodactylus meridionalis (Figure 2D-36 upper) and Coleodactylus sp. (Figure 2D-36 lower).

Eye: Fusion of eyelids is completed, forming a brille. The anterodorsal region becomes thickened, forming the supracilliary fold. The RPE posterior to the iris is further reduced in relation to the iris. The eye appears more rounded, but there is some persistent coloration posterior to the iris.

Comparison with other squamates: Integumentary characters such as the development of scales and claws accelerates in all lizards reviewed. In Phyllopezus pollicaris the scales cover the entire body including the parietal area (Figure 3B-36). The size difference between the preorbital region of the head and maximum diameter of the eye is not very marked in sphaerodactyls, which have a high degree of overlap among the snout bones. This overlap reduces the muzzle unit - a common process in miniaturized forms $[2,75]$. At approximately this stage in Hemidactylus mabouia, Phyllopezus pollicaris, Eublepharis macularius, and other larger lizards in which the snout is not reduced (e.g., Tupinambis merianae, Polychrus acutirostris, Figure 3C-38, 3D-36), the preorbital area starts to become proportionally larger, appearing more like it does in adults. The RPE of sphaerodactyls is more rounded and the differences with other lizards are less marked, although the RPE in other lizards is more concentrated on the iris area. Gekkotans with eyes covered by a brille differ in size from lizards with eyelids (including Eublepharidae) because the eye in the latter starts to be concealed by the thickened eyelids.

\section{Stage 40}

Non-ocular remarks: The external naris appears as a shallow depression, the body is completely covered by scales, and a faint juvenile pigmentation pattern is visible on the dorsum, but not extending onto the limbs. This stage is represented by Gonatodes albogularis (Figure 2A-40).

Eye: The eye approximates the round postnatal form, but some extension of the RPE posterior to the iris is visible.

Comparison with other squamates: Lizard embryos at this point exhibit similar dull coloration. Scales around the eye are almost undifferentiated in both lizards with eyelids and ones with a brille (Figure 2A-40). 


\section{Stage 41}

Non-ocular remarks: The external naris more distinct but remains sealed, pigmentation accentuates and extends to the limbs. This stage is represented by Gonatodes albogularis and G. humeralis (Figure 2A-41, 2B-41).

Eye: The RPE is almost round and restricted to the iris, although there is some posterior extension of the pigmented area covered by the postorbital integument. There are welldefined circumorbital scales around the brille.

Comparison with other squamates: Body coloration becomes darker in all embryos. Circumorbital scales more differentiated in both lizards with eyelids and those with brilles (Figure 2A-41, 2B-41, 3A-41).

\section{Stage 42}

Non-ocular remarks: The external naris opens, pigmentation becomes accentuated, even extended into the abdominal areas. Egg teeth are present on the upper jaw. This stage is represented by Sphaerodactylus macrolepis (Figure 2E-42).

Eye: The RPE is rounded, with the normal circular pupil of sphaerodactylid geckos. At this stage there is no trace of the supracilliary spine, which is present in several sphaerodactylid genera (e.g. Aristelliger, Gonatodes, Lepidoblepharis, and Sphaerodactylus), which, based on this observation, would appear to develop after eclosion.

Comparison with other squamates: The fine details of the integument such as keeling appear during this stage. This can be seen in Eublepharis macularius and Sphaerodactylus macrolepis (Figure 2E-42). At this stage, Sphaerodactylus macrolepis develops keeled scales in the dorsal part of the body and limbs, but they are not elongated and imbricate as in the adults of this species [76]. The condition of unkeeled granular scales is widespread in sphaerodactyls $[31,32,39]$, thus the presence of elongated, keeled, imbricate scales is peramorphic, and it is present in several species of Sphaerodactylus and in the Chatogekko amazonicus complex [2,77,78].

\section{Scleral ossicle development}

Adult lizards, like many vertebrates, have a series of scleral ossicles that form a bony ring external to the optic cup $[79,80]$ which maintains the shape of the eyeball $[81,82]$. In Gonatodes albogularis, Polychrus and Tupinambis, we observed discrete structures in the conjunctival region of the eyes arranged in a circle surrounding the pupillary region (thereofore identified as conjunctival papillae) at stages 32-33. In Gonatodes albogularis the conjunctival papillae show notable reduction between stages 33 and 34, disappearing altogether by stage 35 , indicating that reabsorption took place between these stages (Table 1).

In bird and turtle embryos, the conjunctival papillae appear before the formation of scleral ossicles [83]. The intramembranous ossification of the scleral ossicles has
Table 1 Number of scleral ossicles in geckos; presence and conjunctival papillae counts in each embryonic stage

\begin{tabular}{lccc}
\hline Species & $\begin{array}{c}\text { Adult scleral } \\
\text { ossicles }\end{array}$ & $\begin{array}{c}\text { Developmental } \\
\text { stage }\end{array}$ & $\begin{array}{c}\text { Conjunctival } \\
\text { papillae } \\
\text { condition }\end{array}$ \\
\hline Gonatodes albogularis & 14 & Stage 31 & Absent \\
& 14 & Stage 33 & $\begin{array}{c}\text { Present; } \\
14 \text { papillae }\end{array}$ \\
& 14 & Stage 34 & $\begin{array}{c}\text { Present; } \\
11 \text { papillae }\end{array}$ \\
Gonatodes humeralis & $13-14$ & Stage 35 & Absent \\
Chatogekko amazonicus & $12-14$ & Stage 34 & Absent \\
Sphaerodactylus & $13-14$ & Stage 34 & Absent \\
macrolepis mimetes & & Stage 34 & Absent \\
Hemidactylus mabouia & $?$ & Stage 33 & Absent \\
Phyllopezus pollicaris & $14-15$ & Stage 29 & Absent \\
Polychrus acutirostris & 14 & Stage 33 & Present; \\
& 14 & Pbapillae & Absent \\
Tupinambis merianae & 14 & Stage 29 & Present; \\
& 14 & Stage 33 & 14 papillae \\
\hline & & & \\
\hline
\end{tabular}

been studied in chicken embryos [84,85], and they are found to be induced by the conjunctival papillae and, thickenings of the conjunctival epithelium [86,87]. In a recent study, the presence of the conjunctival papillae was confirmed in the turtle Chelydra serpentina, and it was proposed that this structure plays a similar role in the ossification of the sclerotic ring [85]. The similar position of the scleral ossicles in several groups of Tetrapoda (e.g., chickens and turtles) in conjunction with their similar developmental pattern, has led some authors to claim that they are homologous structures [86]. Our observations of the conjunctival papillae, and their transient apperance in squamate embryos adds evidence to this interpretation of the origin of scleral ossicles in reptiles.

\section{Implications of RPE development in dwarf geckos}

Current observations cover most of the squamate clades, including data for at least 24 taxa represented by fieldcollected embryos and 11 published developmental tables. The pattern of eye development exhibited by the majority of squamates observed involves an outer layer of the optic cup with a RPE that is generally spherical throughout all embryonic stages (Figure 4). This pattern of development is regular across vertebrates $[79,84]$. There is, however, some variation within this widespread pattern, e.g., lacertids seem to exhibit a proportionally small pupil at oviposition (Figure 4). Likewise, the conspicuously deviant pattern observed here only among sphaerodactyl geckos is consistent among all constituent taxa sampled (Figure 4). 


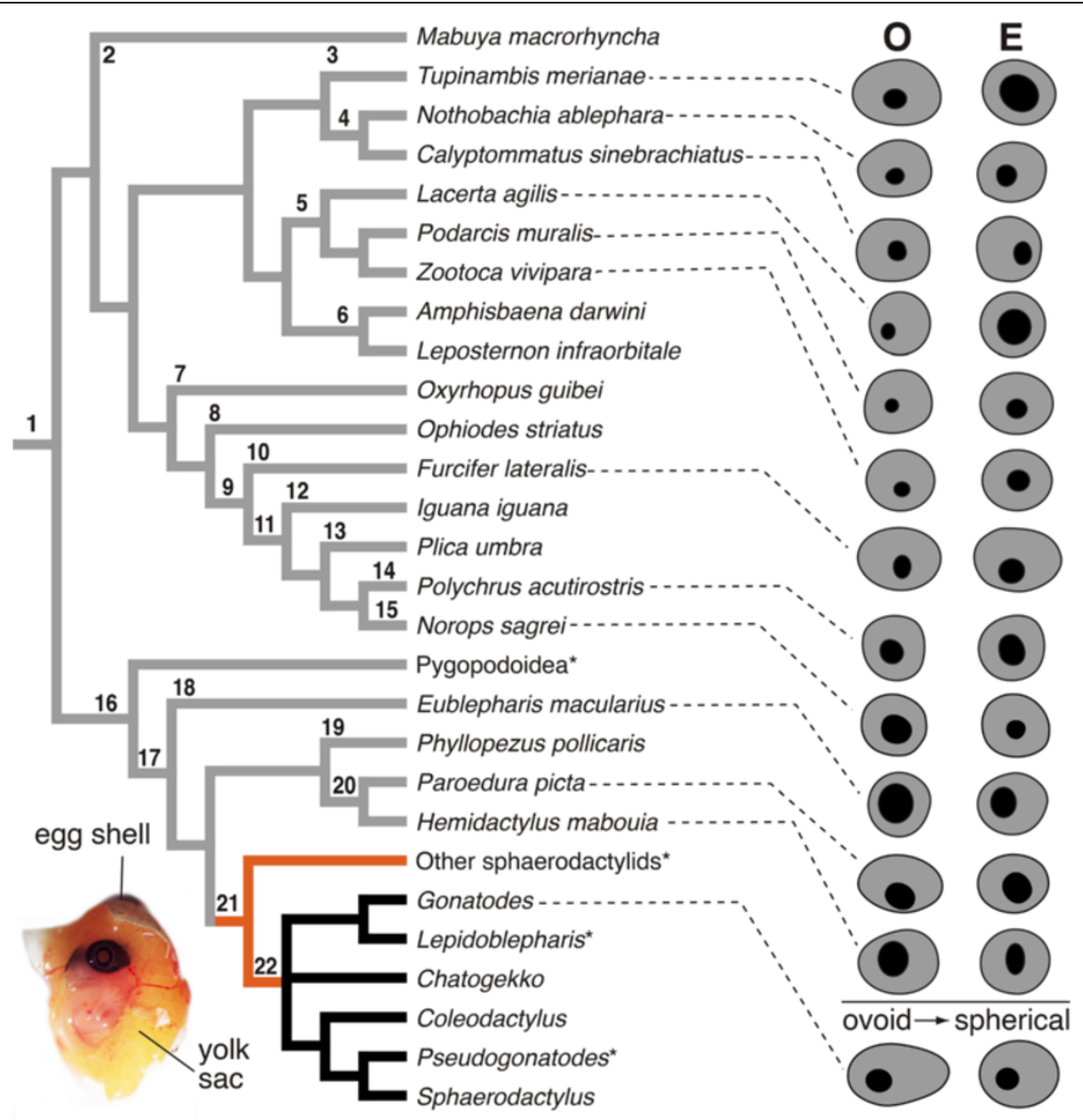

Figure 4 Eye development patterns of the RPE. The terminals in the tree include only those species for which embryological data is available. The two alternative patterns of development of RPE were mapped onto a metatree of Squamata based on molecular hypotheses from four independent studies: Lacertidae [88]; Gekkota [89]; Squamata [90,91]. Gray branches indicate species with the spherical RPE pattern, black branches ovoid $\rightarrow$ spherical RPE pattern. Asterisk indicates taxa not observed; orange branches indicate uncertain character state. Diagrams of the RPE at oviposition (0) and eclosion (E) were redrawn from published figures for those species (see text for references). Numbers on the cladogram correspond to the following taxonomic groups: 1-Squamata, 2-Scincidae, 3-Teiidae, 4-Gymnophthalmidae, 5-Lacertidae, 6-Amphisbaenidae, 7-Serpentes, 8-Anguidae, 9-Iguania, 10-Chamaeleonidae, 11-Iguanoidea, 12-Iguanidae, 13-Tropiduridae, 14-Polychrotidae, 15-Dactyloidae, 16-Gekkota, 17-Gekkonoidea, 18-Eublepharidae, 19-Phyllodactylidae, 20-Gekkonidae, 21-Sphaerodactylidae, 22-Sphaerodactylinae (sphaerodactyls). Inset, Sphaerodactylus macrolepis mimetes egg open to expose embryo (Stage 35).

Sphaerodactyls develop an ovoid RPE at oviposition, which gradually changes into a spherical shape when specimens approach eclosion.

Gekkotans including sphaerodactylids have orbits that lack the postorbital bar $[50,92,93]$. A posteriorly open orbit, allows for an increase of eye size, although the orbit in some gekkotans is completed posteriorly by a postorbital tendon between the jugal and the postorbitofrontal, and bounded by adductor muscles [92-96]. Although a large eye has the potential to accommodate the posterior extension of RPE, eye size and the posterior extension of the RPE are independent, because the observed eye pattern was not present in other gekkotans with similarly modified skulls $[41,44,45]$.

Gonatodes and Spherodactylus have a concaviclivate temporal fovea [22,23], a type of foveal surface that is also found in primates and some birds with a binocular field of vision. This is in contrast to other reptiles and fish that have deep foveae [97]. A concaviclivate fovea contains an additional concentration of cone cells that has also been regarded as an adaptation to diurnal habits $[79,80]$. Since light absorption and filtering are among the functions of the RPE $[98,99]$, this unique development in sphaerodactyls could potentially serve as protection against light damage in these diurnal geckos. Additionally, a posterior extension of the RPE can provide extra retinal protection to the embryo prior to oviposition, which may prevent damage to the embryo from light exposure to through the thin body wall of gravid females (e.g., from basking or foraging) The latter reduction of RPE observed between stages 34 and 37 (Figure 2) can be linked to changes in eye shape, 
development of the brille, and origin of the integumentary pigments, which provide accessory protection to the light sensitive photoreceptor cells.

\section{Conclusions}

The embryonic development of the eye in the Squamata offers a rich source of variation that potentially can provide new phylogenetic information. A developmental pattern in which the RPE in the outer layer of the optic cup is transformed from ovoid to circular is only known in dwarf geckos. Additional observations on genera closely related to this clade (i.e., Aristelliger, Euleptes, Pristurus, Quedenfeldtia, Saurodactylus, and Teratoscincus) are required to determine precise origin and extension of this character within the Family Sphaerodactylidae.

The development of a posterior extension of RPE is postulated as having the potential to provide an auxiliary protective function to the concaviclivate temporal foveae of dwarf geckos, especially prior to oviposition. The evidence supporting this statement is circumstantial and needs to be tested with experimental data and verified in other diurnal geckos with similar retinal structure.

\section{Additional file}

Additional file 1: Material examined Description of data: Material used for description and comparative purposes, includes MZUSP accession numbers and Snout Vent Length (SVL) values for each specimen.

\section{Competing interests}

The authors declare that they have no competing interests.

\section{Authors' contributions}

RAGF, JDD and AMB made substantial intellectual contributions to this study. All authors read and approved the final manuscript.

\section{Acknowledgements}

We thank the following persons for making embryos available for this study: H Zaher, MT Rodrigues, A Camacho, R Recoder, F Curccio and D Pavan. H Zaher, G Montingelli, JC Arredondo, P Bernardo and ES Freitas provided useful comments that improved this manuscript. To $\mathrm{H}$ Zaher for allowing the use of the facilities in Museo de Zoologia da Universidade de São Paulo. JD Daza and AM Bauer were supported by grants DEB 0844523 and DEB 1019943 from the National Science Foundation (USA) and by the Gerald M. Lemole, M.D. Endowed Chair Fund at Villanova University. Additional support for JD Daza was provided by the Department of Biological Sciences and the Office of the Dean of the College of Science at Sam Houston State University.

\section{Author details}

'Museu de Zoologia, Universidade de São Paulo, CP 42.494, 04218-970 São Paulo, Brazil. ${ }^{2}$ Biology Department, Villanova University, 800 Lancaster Avenue, Villanova, PA 19085-1699, USA. 'Department of Biological Sciences, Sam Houston State University, 1900 Avenue I, Huntsville, TX 77341-2116, USA.

Received: 31 July 2013 Accepted: 12 June 2014

Published: 30 June 2014

\section{References}

1. Gamble T, Bauer AM, Greenbaum E, Jackman TR: Evidence for Gondwanan vicariance in an ancient clade of gecko lizards. J Biogeogr 2008, 35:88-104.
2. Gamble T, Daza JD, Colli GR, Vitt L, Bauer AM: A new genus of miniaturized and pug-nosed gecko from South America (Sphaerodactylidae: Gekkota). Zool J Linn Soc 2011, 163:1244-1266.

3. Uetz P, Hošek J, Hallermann J: The reptile database. http://www.reptiledatabase.org.

4. Barbour T: Sphaerodactylus. Mem Mus Comp Zool (Harvard) 1921, 47:217-278.

5. Grant C: The sphaerodactyls of Porto Rico, Culebra and Mona Islands. J Dept Agric PR 1931, 15:199-213.

6. Grant C: A new sphaerodactyl from Porto Rico. J Dept Agric PR 1932, 16:31.

7. Grant C: New sphaerodactyls from Cuba and the Isle of Pines. Herpetologica 1944, 2:118-125.

8. Harris DJ, Kluge AG: The Sphaerodactylus (Sauria: Gekkonidae) of Middle America. Occas Pap Mus Zool Univ Mich 1984, 706:1-59.

9. Thomas R, Hedges SB: Two new geckos (Sphaerodactylus) from the Sierra Martin Garcia of Hispaniola. Herpetologica 1988, 44:96-104.

10. Avila-Pires TCS: Lizards of Brazilian Amazonia (Reptilia: Squamata). Zool Verh 1995, 299:1-706.

11. Kluge AG: Cladistic relationships of sphaerodactyl lizards. Am Mus Novit 1995, 3139:1-23.

12. Thomas R: A new gecko from the Virgin Islands. Q J Fla Acad Sci 1965, 28:117-122.

13. Hedges $S B$, Thomas R: At the lower size limit in amniote vertebrates: a new diminutive lizard from the West Indies. Caribb J Sci 2001, 37:168-173

14. Raxworthy CJ, Nussbaum RA: Systematics, speciation and biogeography of the dwarf chameleons (Brookesia; Reptilia, Squamata, Chamaeleontidae) of Northern Madagascar. J Zool 1995, 235:525-558.

15. Glaw F, Köhler J, Townsend TM, Vences M: Rivaling the World's smallest reptiles: discovery of miniaturized and microendemic new species of leaf chameleons (Brookesia) from Northern Madagascar. PLoS One 2012, 7:e31314.

16. Vitt $\amalg$, Souza RA, Sartorius SS, Avila-Pires TCS, Espósito MC: Comparative ecology of sympatric Gonatodes (Squamata: Gekkonidae) in the Western Amazon of Brazil. Copeia 2000, 2000:83-95.

17. Vitt $L$, Sartorius SS, Avila-Pires TCS, Zani PA, Espósito MC: Small in a big world: ecology of leaf-litter geckos in New World tropical forest. Herpetol Monogr 2005, 19:137-152.

18. Vanzolini PE: O gênero Coleodactylus (Sauria, Gekkonidae). Pap Avulsos Zool (São Paulo) 1957, 13:1-17.

19. Schwartz A: Sphaerodactylus. Cat Am Amph Rept 1973, 142:1-2.

20. Brandley MC, Huelsenbeck JP, Wiens JJ: Rates and patterns in the evolution of snake-like body form in squamate reptiles: evidence for repeated re-evolution of lost digits and long-term persistence of intermediate body forms. Evolution 2008, 62:2042-2064.

21. Bolet A, Evans SE: A tiny lizard (Lepidosauria, Squamata) from the Lower Cretaceous of Spain. Palaeontology 2012, 55:491-500.

22. Underwood G: On the classification and evolution of geckos. Proc Zool Soc Lond 1954, 124:469-492.

23. Röll B: Gecko vision-retinal organization, foveae and implications for binocular vision. Vis Res 2001, 41:2043-2056.

24. Dodt E, Heck J: Retinapotentiale der zapfenfreien Netzhaut des Gecko (Sphaerodactylus muralis). Pflügers Arch Gesamte Physiol Menschen Tiere 1954, 259:226-230.

25. Nava SS, Conway MA, Martins EP: Divergence of visual motion detection in diurnal geckos that inhabit bright and dark habitats. Funct Ecol 2009, 23:794-799.

26. Schwenk K: Feeding in lepidosaurs. In Feeding: Form, Function, and Evolution in Tetrapod Vertebrates. Edited by Schwenk K. San Diego: Academic; 2000:175-291.

27. Underwood G: Reptilian retinas. Nature 1951, 167:183-185.

28. Underwood G: Pupil shape in certain geckos. Copeia 1951, 1951:211-212.

29. Underwood G: Classification of geckos. Nature 1955, 175:1089.

30. Noble GK: The bony structure and phyletic relations of Sphaerodactylus and allied lacertilian genera, with the description of a new genus. Am Mus Novit 1921, 4:1-16.

31. Parker HW: The neotropical lizards of the genera Lepidoblepharis, Pseudogonatodes, Lathrogecko, and Sphaerodactylus, with the description of a new genus. Ann Mag Nat Hist, Series 9 1926, 17:291-301.

32. Vanzolini PE: Lagartos brasileiros da familia Gekkonidae (Sauria). Arquiv Zool (Sao Paulo) 1968, 17:1-84.

33. Vanzolini PE: Geography of the South American Gekkonidae (Sauria). Arquiv Zool (Sao Paulo) 1968, 17:85-112. 
34. Maderson PFA: The structure and evolution of holocrine epidermal glands in Sphaerodactyline and Eublepharine gekkonid lizards. Copeia 1972, 1972:559-571.

35. Moffat LA: The concept of primitiveness and it's bearing on the phylogenetic classification of the Gekkota. Proc Linn Soc New South Wales 1973, 97:275-301.

36. Weber EG: Closure muscles of the external auditory meatus in Gekkonidae. J Herpetol 1973, 7:323-329.

37. Kluge AG: Cladistic relationship in the Gekkonoidea (Squamata, Sauria). Misc Pub Mus Zool Univ Michigan 1987, 173: i-iv + 1-54.

38. Arnold EN: Relationships, evolution and biogeography of semaphore geckos, Pristurus (Squamata, Sphaerodactylidae) based on morphology. Zootaxa 2009, 2060:1-21.

39. Daza JD, Bauer AM: A new amber-embedded sphaerodactyl gecko from Hispaniola, with comments on the morphological synapomorphies of the Sphaerodactylidae. Breviora 2012, 529:1-28.

40. Russell AP, Bauer AM: Underwood's classification of geckos: a 21st century appreciation. Bull Nat Hist Mus Lond Zool Ser 2002, 68:113-121.

41. Werner YL: The ontogenetic development of the vertebrae in some gekkonid lizards. J Morphol 1971, 133:41-92.

42. Brock GT: Some developmental stages in the skulls of geckoes, Lygodactylus capensis and Pachydactylus maculosa, and their bearing on certain important problems in lacertilian craniology. S Afr J Sci 1932, 29:508-532

43. Mahendra BC: Contributions to the bionomics, anatomy, reproduction, and development of the Indian house gecko, Hemidactylus flaviviridis Rüppel. Part I Proc Indian Acad Sci 1936, 4:250-281.

44. Noro M, Uejima A, Abe G, Manabe M, Tamura K: Normal developmental stages of the Madagascar ground gecko Paroedura pictus with special reference to limb morphogenesis. Dev Dyn 2009, 238:100-109.

45. Wise PA, Vickaryous MK, Russell AP: An embryonic staging table for in ovo development of Eublepharis macularius, the leopard gecko. Anat Rec 2009, 292:1198-1212.

46. Ganguly DN, Mitra B: On the structure and development of the vertebral column in the house-gecko, Hemidactylus flaviviridis Rüppel. Anat Anz 1958, 105:4-25.

47. El-Toubi MR, Kamal AM: The development of the skull of Ptyodactylus hasselquistii. I. The development of the chondrocranium. J Morphol 1961 108:63-93.

48. El-Toubi MR, Kamal AM: The development of the skull of Ptyodactylus hasselquistii. II. The fully formed chondrocranium. J Morphol 1961, 108:165-191.

49. El-Toubi MR, Kamal AM: The development of the skull of Ptyodactylus hasselquistii. III. The osteocranium of a late embryo. J Morphol 1961 108:193-202.

50. Rieppel O: The structure of the skull and jaw adductor musculature of the Gekkota, with comments on the phylogenetic relationships of the Xantusiidae (Reptilia: Lacertilia). Zool J Linn Soc 1984, 82:291-318.

51. Evans SE: The Skull of lizards and tuatara. In Biology of the Reptilia, Volume 20, Morphology H. Edited by Gans C, Gaunt S, Adler K. Ithaca: Society for the Study of Amphibians and Reptiles; 2008:1-347.

52. Bellairs A'A: The eyelids and spectacle in geckos. Proc Zool Soc Lond 1948 118:420-425.

53. Adams WE, Pickersgill KW, Underwood G: The development of the carotid arch in Sphaerodactylus argus Gosse, with some remarks on "Inselbildungen" in the aortic arches. J Morphol 1957, 101:399-423.

54. Rosenberg HI, Rusell AP, Cavey MJ: Development of the subdigital adhesive pads of Ptyodactylus guttatus (Reptilia: Gekkonidae). J Morphol 1992, 211:243-258

55. Cohn MJ, Tickle C: Developmental basis of limblessness and axial patterning in snakes. Nature 1999, 399:474-479.

56. Jackson $\mathrm{K}$ : The evolution of venom-conducting fangs: insights from developmental biology. Toxicon 2007, 49:975-981.

57. Vonk FJ, Admiraal JF, Jackson K, Reshef R, de Bakker MA, Vanderschoot $K$, van den Berge I, van Atten M, Burgerhout E, Beck A, Mirtschin PJ, Kochva E, Witte F, Fry BG, Woods AE, Richardson MK: Evolutionary origin and development of snake fangs. Nature 2008, 454:630-633.

58. Peter K: Normentafeln zur Entwicklungsgeschichte der Zauneidechse (Lacerta agilis). In Normentafeln zur Entwicklungsgeschichte der Wirbeltiere. Vol. 4th edition. Edited by Keibel F. Jena: Verlsg Gustav Fischer; 1904:1-165. + 4 pls.

59. Hamburger $\mathrm{V}$, Hamilton $\mathrm{H}$ : A series of normal stages in the development of the chick embryo. J Morphol 1951, 88:49-92.
60. Richardson MK, Hanken J, Gooneratne ML, Pieau C, Raynaud A, Selwood L, Wright GM: There is no highly conserved embryonic stage in the vertebrates: implications for current theories of evolution and development. Anat Embryol 1997, 196:91-106.

61. Boughner JC, Buchtova M, Fu K, Diewert V, Hallgrimsson B, Richman JM: Embryonic development of Python sebae - I: staging criteria and macroscopic skeletal morphogenesis of the head and limbs. Zoology 2007, 110:212-230.

62. Leal F, Tarazona OA, Ramirez-Pinilla MP: Limb development in the gekkonid lizard Gonatodes albogularis: a reconsideration of homology in the lizard carpus and tarsus. J Morphol 2010, 271:1328-1341.

63. Sanger TJ, Losos JB, Gibson-Brown JJ: A developmental staging series for the lizard genus Anolis: a new system for the integration of evolution, development, and ecology. J Morphol 2008, 269:129-137.

64. Dufaure JP, Hubert J: Table de développement du lezard vivipare: Lacerta (Zootoca) vivipara Jacquin. Arch Anat Microsc Morphol Exp 1961, 50:309-328.

65. Muthukkarruppan V, Kanakambika P, Manickavel V, Veeraraghavan K: Analysis of the development of the lizard, Calotes versicolor, I. A series of normal stages in the embryonic development. J Morphol 1970, 130:479-490.

66. Blanc F: Table de développement de Chamaeleo lateralis Gray, 1831 Ann Embryol Morphol 1974, 7:99-115.

67. Dhouailly D, Saxod R: Les stades du développement de Lacerta muralis Laurent entre la ponte et l'éclosion. Bull Soc Zool France 1974, 99:489-494.

68. Montero R, Gans C, Lions ML: Embryonic development of the skeleton of Amphisbaena darwini heterozonata (Squamata: Amphisbaenidae). J Morphol 1999, 239:1-25.

69. Roscito JG, Rodrigues MT: Embryonic development of the fossorial gymnophthalmid lizards Nothobachia ablephara and Calyptommatus sinebrachiatus. Zoology 2012, 115:302-318.

70. Maddison WP, Maddison DR: Mesquite: a modular system for evolutionary analysis. Version 2.75 2011, http://mesquiteproject.org

71. Camp CL: Classification of the lizards. Bull Am Mus Nat Hist 1923, 48:289-307.

72. Conrad JL: Phylogeny and systematics of Squamata (Reptilia) based on morphology. Bull Am Mus Nat Hist 2008, 310:1-182.

73. Guerra-Fuentes RA, Roscito JG, Sales Nunes PM, Oliveira-Bastos PR, Antoniazzi MM, Jared C, Rodrigues MT: Through the looking glass: the spectacle in gymnophthalmid lizards. Anat Rec 2014, 297:496-504.

74. Hubert J, Dufaure JP: Table de développement de la vipère aspic, Vipera aspis L. Bull Soc Zool France 1968, 93:135-148.

75. Daza JD, Abdala V, Thomas R, Bauer AM: Skull anatomy of the miniaturized gecko Sphaerodactylus roosevelti (Squamata: Gekkota). J Morphol 2008, 269:1340-1364.

76. Thomas R, Schwartz A: Sphaerodactylus (Gekkonidae) in the greater Puerto Rico region. Bull Fla State Mus 1966, 10:193-260.

77. Moretti R: Revisão Taxonômica e Biogeografia do Gênero Coleodactylus Parker, 1926 (Squamata: Sphaerodactylidae), PhD thesis. São Paulo, Brazil: Universidade de Saô Pablo, Instituto de Biociências; 2009.

78. Geurgas SR, Rodrigues MT: The hidden diversity of Coleodactylus amazonicus (Sphaerodactylinae, Gekkota) revealed by molecular data. Mol Phyl Evol 2010, 54:583-593.

79. Walls GL: The vertebrate eye and its adaptive radiation. Bloomfield Hills: Cranbook Institute of Science; 1942

80. Underwood G: The Eye. In Biology of the Reptilia, Volume 2, Morphology B Edited by Gans C and Parsons TS. London: Academic; 1970:1-97.

81. Romer AS: The Vertebrate Body 4th Edition. Philadelphia: WB Saunders Company; 1970.

82. de Queiroz K: The scleral ossicles of sceloporine iguanids: a reexamination with comments on their phylogenetic significance. Herpetologica 1982, 38:302-311.

83. Duench $K$, Franz-Odendaal TA: BMP and hedgehog signaling during development of scleral ossicles. Dev Biol 2012, 365:251-258.

84. Chow RL, Lang RA: Early eye development in vertebrates. Annu Rev Cell Dev Biol 2001, 17:255-296.

85. Franz-Odendaal TA: Intramembranous ossification of scleral ossicles in Chelydra serpentina. Zoology 2006, 109:75-81.

86. Hall BK: Bones and Cartilage. Developmental and Evolutionary Skeletal Biology. London: Elsevier Academic Press; 2005.

87. Franz-Odendaal TA, Hall BK: Skeletal elements within teleost eyes and a discussion of their homology. J Morphol 2006, 267:1326-1337. 
88. Werner M, Mihaela P: The phylogeny of the family Lacertidae (Reptilia) based on nuclear DNA sequences: convergent adaptations to arid habitats within the subfamily Eremiainae. Mol Phyl Evol 2007, 44:1155-1163.

89. Gamble T, Greenbaum E, Russell AP, Jackman TR, Bauer AM: Repeated origin and loss of toepads in gekkotan lizards. PLoS One 2012, 7:e39429.

90. Wiens JJ, Hutter CR, Mulcahy DG, Noonan BP, Townsend TM, Sites JW Jr, Reeder TW: Resolving the phylogeny of lizards and snakes (Squamata) with extensive sampling of genes and species. Biol Lett 2012, 8:1043-1046.

91. Pyron RA, Burbrink FT, Wiens JJ: A phylogeny and revised classification of Squamata, including 4161 species of lizards and snakes. BMC Evol Biol 2013, 13:93.

92. McDowell SBJ, Bogert CM: The systematic position of Lanthanotus and the affinities of the anguinomorphan lizards. Bull Am Mus Nat Hist 1954, 105:1-42.

93. Daza JD, Bauer AM: The circumorbital bones of the Gekkota (Reptilia: Squamata). Anat Rec 2010, 293:402-413.

94. Daza JD, Diogo R, Johnston P, Abdala V: Jaw adductor muscles across lepidosaurs: a reappraisal. Anat Rec 2011, 294:1765-1782.

95. Stephenson NG, Stephenson EM: The osteology of the New Zealand geckos and its bearing in their morphological status. Trans Roy Soc N Z 1956, 84:341-358.

96. Wise PAD, Russell AP: Development of the dorsal circumorbital bones in the leopard gecko (Eublepharis macularius) and its bearing on the homology of these elements in the Gekkota. Anat Rec 2010, 293:2001-2006.

97. Harkness $L$, Bennet-Clark HC: The deep fovea as a focus indicator. Nature 1978, 272:814-816

98. Marmor MF, Wolfensberger TJ: The Retinal Pigment Epithelium: Function and Disease. New York: Oxford University Press; 1998.

99. Strauss O: The retinal pigment epithelium in visual function. Physiol Rev 2005, 85:845-881.

doi:10.1186/1471-213X-14-29

Cite this article as: Guerra-Fuentes et al:: The embryology of the retinal pigmented epithelium in dwarf geckos (Gekkota: Sphaerodactylinae): a unique developmental pattern. BMC Developmental Biology 2014 14:29.

\section{Submit your next manuscript to BioMed Central and take full advantage of:}

- Convenient online submission

- Thorough peer review

- No space constraints or color figure charges

- Immediate publication on acceptance

- Inclusion in PubMed, CAS, Scopus and Google Scholar

- Research which is freely available for redistribution 